Short Communication

\title{
MMP-2 geno-phenotype is prognostic for colorectal cancer survival, whereas MMP-9 is not
}

\author{
AMJ Langers', CFM Sier,', LJAC Hawinkels', FJGM Kubben', W van Duijn', JJ van der Reijden', \\ CBHW Lamers', DW Hommes' and HW Verspaget' \\ 'Department of Gastroenterology-Hepatology, Leiden University Medical Centre, Leiden, The Netherlands
}

The prognostic significance of single-nucleotide polymorphisms (SNPs) and tumour protein levels of MMP-2 and MMP-9 was evaluated in 215 colorectal cancer patients. Single-nucleotide polymorphism MMP-2_1306T and high MMP-2 levels were significantly associated with worse survival. Extreme tumour MMP-9 levels were associated with poor prognosis but SNP MMP-9 - 1562C>T was not. Tumour MMP levels were not determined by their SNP genotypes.

British Journal of Cancer (2008) 98, I820- |823. doi:I0.1038/sj.bjc.6604380 www.bjcancer.com

Published online 27 May 2008

(c) 2008 Cancer Research UK

Keywords: metalloproteinase; SNP; survival; prognosis

Enhanced tumour matrix metalloproteinase (MMP) levels have been correlated to decreased patients' survival in various types of cancer (Sienel et al, 2003; Pellikainen et al, 2004; Kubben et al, 2006b; Hilska et al, 2007; de Vicente et al, 2007). Next to sheer degraders of extracellular matrix, MMPs are presently regarded as general molecular switches in the microenvironment (Overall and Blobel, 2007). For instance, MMPs function as major regulators of tumour growth by catalysing the release or activation of growth factors, activation or shedding of membrane receptors, or cleavage of matrix/membrane-bound substrates involved in cell proliferation (Cauwe et al, 2007). A subgroup of MMPs, the gelatinases (MMP-2 and MMP-9), have been particularly implicated in progression, angiogenesis and metastasis of various cancer types (Turpeenniemi-Hujanen, 2005). In the present study, we evaluated the association between, and the prognostic relevance of tissue protein levels of MMP-2 and MMP-9 and their gene promoter single-nucleotide polymorphisms (SNPs) in a cohort of 215 Dutch colorectal cancer patients.

\section{MATERIALS AND METHODS}

\section{Patients and study design}

Representative, nonnecrotic samples of cancer tissue were collected from 215 patients with colorectal cancer, operated in the Leiden University Medical Centre (December 1983-September 1991). Tissues were snap-frozen and stored at $-70^{\circ} \mathrm{C}$. Clinical data and follow-up were available for at least 10 years. Macroscopic and microscopic parameters were obtained from the pathology reports. The study was performed according to the instructions and guidelines of the LUMC Medical Ethics Committee.

\footnotetext{
*Correspondence: Dr CFM Sier, Department of GastroenterologyHepatology, Leiden University Medical Centre, PO Box 9600, Leiden 2300 RC, The Netherlands; E-mail: c.f.m.sier@lumc.nl

Received 4 February 2008; revised 8 April 2008; accepted 8 April 2008; published online 27 May 2008
}

\section{Tissue preparation and protein concentration}

Tissues were homogenised in $0.1 \mathrm{M}$. Tris-HCL ( $\mathrm{pH}$ 7.5) with $0.1 \%(\mathrm{v} / \mathrm{v})$ Tween 80 buffer and centrifuged twice all at $4^{\circ} \mathrm{C}$, as described before (Sier et al, 1991), the protein concentrations were determined (Lowry et al, 1951) and the supernatants were aliquoted and stored at $-70^{\circ} \mathrm{C}$. Storage-induced degradation of MMP-2 and MMP-9 was checked by western blots and gelatin zymography prior to ELISA measurements (Sier et al, 1996).

\section{Determination of MMP-2 and MMP-9 in tissue homogenates}

The MMP-2 and MMP-9 levels were determined by previously described ELISAs (Gao et al, 2005). Polyclonal anti-MMP-2 or monoclonal anti-MMP-9 antibodies were used as catching antibody, incubated with appropriately diluted samples $\left(\mathrm{o} / \mathrm{n}, 4^{\circ} \mathrm{C}\right)$, and polyclonal anti-MMP-2/biotin-labelled goat anti-rabbit-IgG and biotin-labelled polyclonal anti-MMP-9 antibodies for immunedetection combined with avidin-peroxidase and the $3,3^{\prime}, 5,5^{\prime}$ tetramethyl benzidine $/ \mathrm{H}_{2} \mathrm{O}_{2}$ substrate solution, and the absorption was read at $450 \mathrm{~nm}$. Sample MMP concentrations were calculated from standard curves and expressed in ng per mg protein.

\section{Single-nucleotide polymorphism analysis}

Tissue DNA was isolated using the salting out method (Miller et al, 1988). Single-nucleotide polymorphism (SNP) analysis for MMP- $2_{-1306 \mathrm{C}>\mathrm{T}}$ and MMP-9 $-1562 \mathrm{C}>\mathrm{T}$ was performed by tetraprimer ARMS PCR, involving four oligonucleotide primers but no restriction enzymes, or RFLP-PCR, as described earlier (Meijer et al, 2006; Kubben et al, 2006a).

\section{Statistical analysis}

Statistical analyses were performed using SPSS 12.0 Statistical Package (2004; SPSS Inc., Chicago, IL, USA). Expression differences between groups were calculated using the Mann-Whitney's 
$U$-test. Log-rank statistics was used for optimal cutoff point analysis. Hardy-Weinberg's analysis was performed using $\chi^{2}$ or Fisher's exact test to examine differences in the distribution of alleles and genotypes. Correlations between parameters were according to Pearson or Spearman, where appropriate. Overall survival curves were according to Kaplan and Meier. Univariate and multivariate survival analyses were performed using the Cox's proportional hazards method. $P$-values $\leqslant 0.05$ were considered significant.

\section{RESULTS}

The genotype distributions of the SNPs for MMP-2 and MMP-9 in 215 colorectal cancer patients are shown in Table 1. The distribution of the polymorphisms in the patients was according to the predicted Hardy-Weinberg's distribution. Both SNPs showed a weak but significant association with TNM stage (Table 1) and MMP- $2_{-1306 C}>\mathrm{T}$ also with survival (Figure 1A). All other clinicopathological parameters did not show an association with either SNP MMP-2 $-1306 \mathrm{C}>\mathrm{T}$ or MMP-9 $-1562 \mathrm{C}>\mathrm{T}$, and the latter was also not associated with survival (Figure $1 \mathrm{~B}$ ).

The protein levels of MMP-2 (median 10.6; range: $0.0-76.6 \mathrm{ng}$ per mg protein) and MMP-9 (median 37.3; range: $0.5-201.9 \mathrm{ng}$ per $\mathrm{mg}$ protein) in the colorectal carcinomas were found not to be

Table I Genotype distribution of single-nucleotide polymorphisms (SNPs) for MMP-2 and MMP-9 in 2I5 colorectal carcinoma patients compared with the expected Hardy-Weinberg distribution $(\mathrm{H}-\mathrm{W})$

\begin{tabular}{|c|c|c|c|c|c|c|}
\hline \multirow{2}{*}{$\begin{array}{l}\text { SNP } \\
\text { genotype }\end{array}$} & \multirow[b]{2}{*}{ H-W } & \multirow{2}{*}{$\begin{array}{c}\text { All } \\
\text { patients }\end{array}$} & \multicolumn{4}{|c|}{ TNM stage* } \\
\hline & & & $\mathbf{I}$ & 2 & 3 & 4 \\
\hline MMP-2 $-1306 \mathrm{C}>T$ & (\%) & $\%(N)$ & $\%(N)$ & $\%(N)$ & $\%(N)$ & $\%(N)$ \\
\hline CC & 55.4 & $54.4(1 \mid 7)$ & $69.4(25)$ & 57.1 (48) & $52.2(35)$ & $32.1(9)$ \\
\hline $\mathrm{CT}$ & 38.1 & $40.0(86)$ & $27.8(10)$ & $40.5(34)$ & $41.8(28)$ & $50.0(14)$ \\
\hline$\pi$ & 6.6 & $5.6(12)$ & $2.8(I)$ & $2.4(2)$ & $6.0(4)$ & $17.9(5)$ \\
\hline \multicolumn{7}{|l|}{ MMP-9 $-1562 C>T$} \\
\hline CC & 69.7 & $71.2(153)$ & $83.3(30)$ & $70.2(59)$ & 73.1 (49) & $53.6(15)$ \\
\hline $\mathrm{CT}$ & 27.6 & $24.7(53)$ & $|1$.$| (4)$ & $28.6(24)$ & $23.9(16)$ & 32.1 (9) \\
\hline$\pi$ & 2.7 & $4.1(9)$ & $5.6(2)$ & $1.2(1)$ & $3.0(2)$ & 14.3 (4) \\
\hline
\end{tabular}

MMP $=$ matrix metalloproteinase $* \chi^{2}$ values for TNM stage distribution of MMP-2 and MMP-9 were, respectively, I5.9 $(P=0.01)$ and I $4.9(P=0.02)$

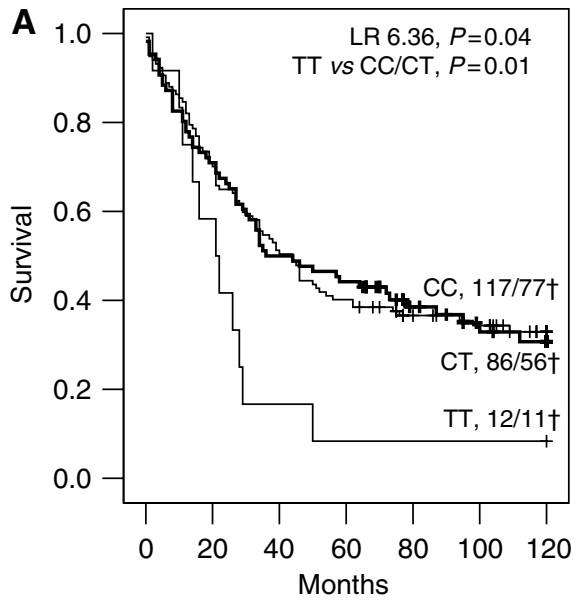

related to any of the clinicopathological parameters, although for MMP-2 a stepwise increase with TNM stage was discernable (not shown). For the survival analysis, an optimised cutoff point value was identified for the tumour MMP-2 level (18.5 ng per mg protein, LR 5.07, $P=0.024$, Figure 2A). The same approach for MMP-9 resulted in two differently oriented cutoff points; a low MMP-9 value (11.2 ng per mg protein, LR 9.18, $P=0.010$ ) and a high value (125.0 ng per mg protein, LR 5.31, $P=0.021$ ), both associated with poor prognosis (Figure $2 \mathrm{~B}$ ).

The MMP-2 and MMP-9 protein levels in the colorectal cancer homogenates did not correlate with their respective SNP genotypes. The median values for MMP- $2_{-1306 \mathrm{C}>\mathrm{T}}$ were $10.9,9.5$ and $11.6 \mathrm{ng} \mathrm{mg}^{-1}$ for genotypes CC, CT and TT, respectively. Even an apparent enhancement of MMP-9 protein associated with the TT genotype of SNP MMP-9 $-1562 \mathrm{C}>\mathrm{T}$ in tumours did not reach significance (CC/CT vs TT, medians $36.5 / 26.3$ vs $44.4 \mathrm{ng} \mathrm{mg}^{-1}$, $P=0.28)$.

Univariate Cox's survival analyses confirmed the association of the MMP-2 SNP and the protein levels of MMP-2 and MMP-9 with survival (Table 2). Multivariate analysis against the prognosisassociated parameters gender, age and TNM classification showed that the MMP-2 SNP was independently associated with survival, whereas the tumour protein levels of MMP-2 just lost and MMP-9 completely lost their significance.

\section{DISCUSSION}

MMP-2 and MMP-9 are proteinases implicated in cancer progression. We showed previously that high tumour levels of MMP-2 in gastric carcinomas were consistently associated with a worse survival (Sier et al, 1996; Kubben et al, 2006b). For enhanced MMP-9 levels, the relation with survival was more ambivalent (Kubben et al, 2006b, 2007). Also in our present cohort of colorectal carcinoma patients, we found that MMP-2 and MMP-9 levels within the tumours are of significance to survival. The cutoff point analysis showed a broad range of MMP-2 levels with a significant and unidirectional relation with survival outcome: high tumour MMP-2 levels are unfavourable for the patients' prognosis. Our ELISA-derived MMP-2 data correspond very well with a recent immunohistochemical study in a group of 351 colorectal cancer patients, showing that high expression of MMP-2 in malignant epithelium as well as in the surrounding stroma was associated with reduced survival (Hilska et al, 2007). Similar analysis on our tumour MMP-9 data revealed that not only patients with the highest, but also those with the lowest levels had a worse survival

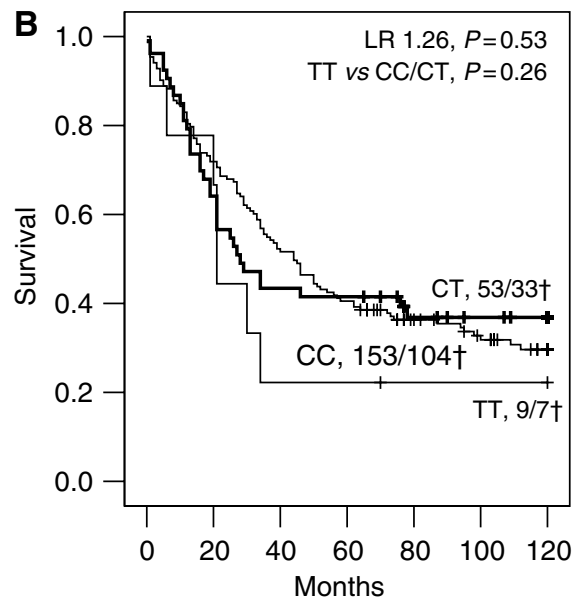

Figure I Kaplan-Meier's 10-year survival curves of 215 colorectal cancer patients grouped by their genotype for SNP MMP-2 $-1306 \mathrm{C}>\mathrm{T}$ (A) and MMP-9 $-1562 C>T$ (B). The total number of patients and the deceased patients $(\dagger)$ are indicated per subgroup. 

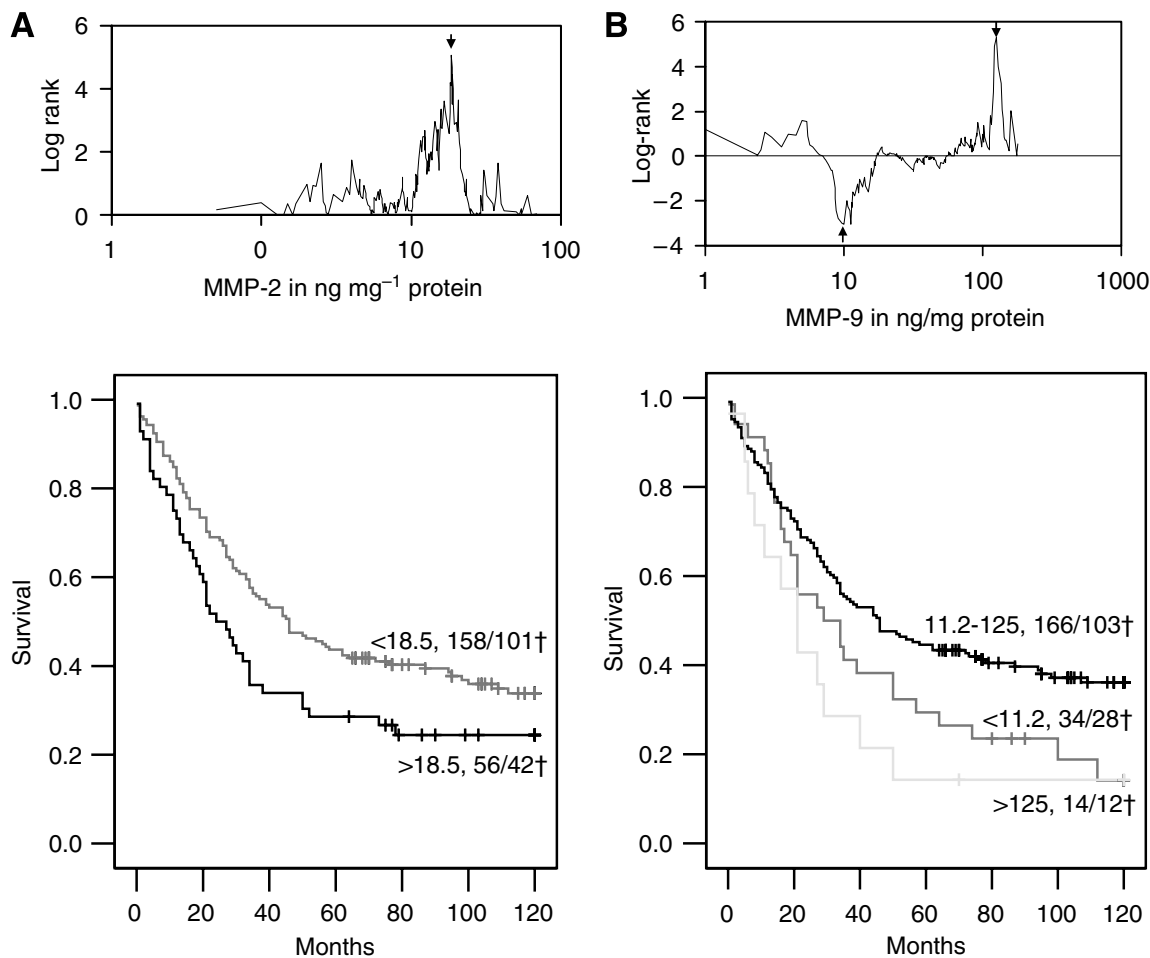

Figure 2 Optimal cutoff point analysis and corresponding Kaplan-Meier's l0-year survival curves for MMP-2 (A) and MMP-9 (B) in tumour tissue homogenates from 215 colorectal cancer patients. The optimal cutoff points are indicated with arrows. In the survival curves, the total number of patients and the deceased patients $(\dagger)$ are indicated per subgroup.

Table 2 Univariate and multivariate Cox's proportional hazard 10-year survival analysis of 215 colorectal cancer patients

\begin{tabular}{|c|c|c|c|c|c|c|c|c|}
\hline & & $n$ & \multicolumn{3}{|c|}{ Univariate } & \multicolumn{3}{|c|}{ Multivariate } \\
\hline Gender & Fvs M & $91-124$ & 1.363 & $0.973-0908$ & 0.071 & 1.362 & $0.973-1.908$ & 0.072 \\
\hline Age & $<65$ years $>$ & $73-142$ & 2.123 & $1.448-3.113$ & 0.000 & 2.390 & $1.625-3.516$ & 0.000 \\
\hline TNM & $1 / 2$ vs $3 / 4$ & $120-95$ & 2.316 & $1.662-3.228$ & 0.000 & 2.548 & $1.822-3.564$ & 0.000 \\
\hline Localisation & Right vs rest & $75-140$ & 1.023 & $0.726-1.442$ & 0.896 & & Not included & \\
\hline \multicolumn{9}{|l|}{ MMP proteins } \\
\hline MMP-2 & $<18.5 \mathrm{ng} \mathrm{mg}^{-1}>$ & $158-56$ & 1.504 & $1.048-2.158$ & 0.027 & 1.417 & $0.982-2.043$ & 0.062 \\
\hline \multirow[t]{3}{*}{ MMP-9 } & $11.2-125^{\circ}$ & 166 & 1.000 & & & & & \\
\hline & $<11.2$ & 34 & 1.526 & $1.004-2.319$ & 0.048 & 0.787 & $0.516-1.201$ & 0.266 \\
\hline & $>125$ & 14 & 2.135 & $|.17|-3.895$ & 0.013 & 1.109 & $0.561-2.189$ & 0.766 \\
\hline
\end{tabular}

$\mathrm{Cl}=$ confidence interval; $\mathrm{HR}=$ hazard ratio; $\mathrm{MMP}=$ matrix metalloproteinase. Multivariate analysis was performed by adding every single $\mathrm{MMP}$-related parameter to the dichotomised, prognosis-associated clinicopathological parameters gender, age and TNM stage. Entries in bold indicate significant, or in case of MMP-2 almost significant $P$-values.

than patients with intermediate levels. Duality of tumour MMP-9 levels with respect to survival has been recognised before in immunohistochemistry-based studies. For example, extensive MMP-9 staining in ovarian cancer cells was associated with a longer survival, as opposed to a shorter survival with a higher stromal expression of MMP-9 (Sillanpaa et al, 2007). Earlier morphometric studies indicated that the degree of MMP-9 expression in tumour-associated lymphocytes, macrophages and neutrophils was inversely associated with invasion and metastasis in colorectal cancer (Takeha et al, 1997). These observations are relevant to our findings because a low level of MMP-9 in the tumour homogenates might indicate a lack of infiltration of the tumours with MMP-9 containing leukocytes, known to exert anticancer effects (Nielsen et al, 1996; Owen et al, 2004), leading to an adverse prognosis. In addition, MMP-9-mediated cleavage of extracellular matrix components is also known to generate antiangiogenesis inhibitors like angiostatin (Patterson and Sang, 1997). Low MMP-9 expression in the tumour, leading to insufficient production of antiangiogenic factors, could also contribute to the worse prognosis of these patients (Pozzi et al, 2002). However, MMP-9 has a wide range of substrates, including various growth factors and several types of collagen, 
which after cleavage contribute to the process of invasion, angiogenesis and metastasis of tumours, explaining why high tumour levels of MMP-9, in general, are associated with a poor prognosis.

Differences in expression of metalloproteinases might, in part, be explained by genotypic variation. Because the investigated SNPs of MMP-2 and MMP-9 are located in the promoter region of the gene, a correlation between polymorphism and protein expression might be expected. The $\mathrm{C} \rightarrow \mathrm{T}$ transition at the -1306 position of the MMP-2 gene promoter prevents binding of the stimulating Sp1 transcription factor, whereas a change at the -1562 position of the MMP-9 gene decreases binding of a repression factor (Zhang et al, 1999; Price et al, 2001). In vitro MMP-2 expression levels by colon cancer cell lines containing the CC genotype were indeed higher compared with cells with the CT genotype (Xu et al, 2004). In our cohort of patients, however, we found no relationship between MMP-2 and MMP-9 polymorphisms and the tumour protein levels, likely caused by the complicated regulatory posttranslational

\section{REFERENCES}

Cauwe B, Van den Steen PE, Opdenakker G (2007) The biochemical, biological, and pathological kaleidoscope of cell surface substrates processed by matrix metalloproteinases. Crit Rev Biochem Mol Biol 42: 113-185 de Vicente JC, Lequerica-Fernandez P, Santamaria J, Fresno MF (2007) Expression of MMP-7 and MT1-MMP in oral squamous cell carcinoma as predictive indicator for tumor invasion and prognosis. J Oral Pathol Med 36: $415-424$

Gao Q, Meijer MJ, Kubben FJ, Sier CF, Kruidenier L, Van Duijn W, van den Berg M, Van Hogezand RA, Lamers CB, Verspaget HW (2005) Expression of matrix metalloproteinases-2 and -9 in intestinal tissue of patients with inflammatory bowel diseases. Dig Liver Dis 37: $584-592$

Hilska M, Roberts PJ, Collan YU, Laine VJ, Kossi J, Hirsimaki P, Rahkonen O, Laato M (2007) Prognostic significance of matrix metalloproteinases$1,-2,-7$ and -13 and tissue inhibitors of metalloproteinases-1, $-2,-3$ and -4 in colorectal cancer. Int J Cancer 121: 714-723

Kubben FJ, Sier CF, Hawinkels LJ, Tschesche H, Van Duijn W, Zuidwijk K, Van der Reijden JJ, Hanemaaijer R, Griffioen G, Lamers CB, Verspaget HW (2007) Clinical evidence for a protective role of lipocalin-2 against MMP-9 autodegradation and the impact for gastric cancer. Eur J Cancer 43: $1869-1876$

Kubben FJ, Sier CF, Meijer MJ, van den BM, Van der Reijden JJ, Griffioen G, van de Velde CJ, Lamers CB, Verspaget HW (2006a) Clinical impact of MMP and TIMP gene polymorphisms in gastric cancer. $\mathrm{Br} J$ Cancer 95: $744-751$

Kubben FJ, Sier CF, Van Duijn W, Griffioen G, Hanemaaijer R, van de Velde CJ, van Krieken JH, Lamers CB, Verspaget HW (2006b) Matrix metalloproteinase-2 is a consistent prognostic factor in gastric cancer. Br J Cancer 94: 1035-1040

Lowry OH, Rosebrough NJ, Farr AL, Randall RJ (1951) Protein measurement with the Folin phenol reagent. J Biol Chem 193: 265-275

Meijer MJ, Mieremet-Ooms MA, Van Duijn W, van der Zon AM, Hanemaaijer R, Verheijen JH, Van Hogezand RA, Lamers CB, Verspaget HW (2006) Effect of the anti-tumor necrosis factor-alpha antibody infliximab on the ex vivo mucosal matrix metalloproteinase-proteolytic phenotype in inflammatory bowel disease. Inflamm Bowel Dis 13: 200-210

Miller SA, Dykes DD, Polesky HF (1988) A simple salting out procedure for extracting DNA from human nucleated cells. Nucleic Acids Res 16: 1215

Nielsen BS, Timshel S, Kjeldsen L, Sehested M, Pyke C, Borregaard N, Danø $\mathrm{K}$ (1996) $92 \mathrm{kDa}$ type IV collagenase (MMP-9) is expressed in neutrophils and macrophages but not in malignant epithelial cells in human colon cancer. Int J Cancer 65: 57-62

Overall CM, Blobel CP (2007) In search of partners: linking extracellular proteases to substrates. Nat Rev Mol Cell Biol 8: 245-257

Owen JL, Iragavarapu-Charyulu V, Lopez DM (2004) T cell-derived matrix metalloproteinase-9 in breast cancer: friend or foe? Breast Dis 20: 145-153

Patterson BC, Sang QA (1997) Angiostatin-converting enzyme activities of human matrilysin (MMP-7) and gelatinase B/type IV collagenase (MMP-9). J Biol Chem 272: 28823-28825

Pellikainen JM, Ropponen KM, Kataja VV, Kellokoski JK, Eskelinen MJ, Kosma VM (2004) Expression of matrix metalloproteinase (MMP)-2 and mechanisms for proteinases in multicellular tumour tissues. Nevertheless, we did find significant associations between MMP- $2_{-1306 \mathrm{C}>\mathrm{T}}$ and TNM stage and survival, that is, worse prognosis in patients with the TT genotype. This association with the outcome of the patients support the recent confirmation of MMP-2 as one of the candidate cancer genes (CAN genes) by the number and nature of mutations and pathways in colorectal cancer (Sjöblom et al, 2006). Our results for SNP MMP-9 $-1562 \mathrm{C}>\mathrm{T}$ correspond well with data from Asiatic patients (Xu et al, 2007), indicating that this polymorphism is not directly involved in the process of colorectal carcinogenesis.

Summarising, we showed that MMP-9, mechanistically probably the most interesting of the gelatinases, is not a likely candidate as a simple prognostic indicator. Despite the absence of a correlation between promoter-located SNP $-1306 \mathrm{C}>\mathrm{T}$ in the MMP-2 gene with tumour MMP-2 levels, both parameters were significantly associated with survival, indicating MMP-2 as a consistent independent prognostic factor in colorectal cancer.
MMP-9 in breast cancer with a special reference to activator protein-2, HER2, and prognosis. Clin Cancer Res 10: 7621-7628

Pozzi A, LeVine WF, Gardner HA (2002) Low plasma levels of matrix metalloproteinase 9 permit increased tumor angiogenesis. Oncogene 21: $272-281$

Price SJ, Greaves DR, Watkins H (2001) Identification of novel, functional genetic variants in the human matrix metalloproteinase-2 gene - role of Sp1 in allele-specific transcriptional regulation. J Biol Chem 276: $7549-7558$

Sienel W, Hellers J, Morresi-Hauf A, Lichtinghagen R, Mutschler W, Jochum M, Klein C, Passlick B, Pantel K (2003) Prognostic impact of matrix metalloproteinase-9 in operable non-small cell lung cancer. Int J Cancer 103: 647-651

Sier CF, Kubben FJ, Ganesh S, Heerding MM, Griffioen G, Hanemaaijer R, van Krieken JH, Lamers CB, Verspaget HW (1996) Tissue levels of matrix metalloproteinases MMP-2 and MMP-9 are related to the overall survival of patients with gastric carcinoma. Br J Cancer 74: 413-417

Sier CF, Verspaget HW, Griffioen G, Verheijen JH, Quax PH, Dooijewaard G, De Bruin PA, Lamers CB (1991) Imbalance of plasminogen activators and their inhibitors in human colorectal neoplasia. Implications of urokinase in colorectal carcinogenesis. Gastroenterology 101: 1522-1528

Sillanpaa S, Anttila M, Voutilainen K, Ropponen K, Turpeenniemi-Hujanen T, Puistola U, Tammi R, Tammi M, Sironen R, Saarikoski S, Kosma VM (2007) Prognostic significance of matrix metalloproteinase-9 (MMP-9) in epithelial ovarian cancer. Gynecol Oncol 104: 296-303

Sjöblom T, Jones S, Wood LD, Parsons DW, Lin J, Barber TD, Mandelker D, Leary RJ, Ptak J, Silliman N, Szabo S, Buckhaults P, Farrell C, Meeh P, Markowitz SD, Willis J, Dawson D, Willson JK, Gazdar AF, Hartigan J, Wu L, Liu C, Parmigiani G, Park BH, Bachman KE, Papadopoulos N, Vogelstein B, Kinzler KW, Velculescu VE (2006) The consensus coding sequences of human breast and colorectal cancers. Science 314: 268-274

Takeha S, Fujiyama Y, Bamba T, Sorsa T, Nagura H, Ohtani H (1997) Stromal expression of MMP-9 and urokinase receptor is inversely associated with liver metastasis and with infiltrating growth in human colorectal cancer: a novel approach from immune/inflammatory aspect. Jpn J Cancer Res 88: 72-81

Turpeenniemi-Hujanen T (2005) Gelatinases (MMP-2 and -9) and their natural inhibitors as prognostic indicators in solid cancers. Biochimie 87: $287-297$

Xu E, Lai M, Lv B, Xing X, Huang Q, Xia X (2004) A single nucleotide polymorphism in the matrix metalloproteinase-2 promoter is associated with colorectal cancer. Biochem Biophys Res Commun 324: 999-1003

Xu E, Xia X, Lu B, Xing X, Huang Q, Ma Y, Wang W, Lai M (2007) Association of matrix metalloproteinase-2 and -9 promoter polymorphisms with colorectal cancer in Chinese. Mol Carcinog 46: 924-929

Zhang B, Ye S, Herrmann SM, Eriksson P, de Maat M, Evans A, Arveiler D, Luc G, Cambien F, Hamsten A, Watkins H, Henney AM (1999) Functional polymorphism in the regulatory region of gelatinase $\mathrm{B}$ gene in relation to severity of coronary atherosclerosis. Circulation 99: $1788-1794$ 